\title{
PERFORMANCE OF SOME CHEMICAL COMPOUNDS AND NEEM OIL IN CONTROLLING WHITE STEM ROT AND IMPROVING CHICKPEA PRODUCTIVITY \\ Rahmou, A. A. ${ }^{1}$; A. H. El-Shaer ${ }^{2}$ and I. A .Ismail ${ }^{2}$ \\ 'Soil, Water and Environ. Research Institute, ARC. Giza, Egypt. \\ 2Plant Pathology Research Institute, ARC, Giza, Egypt.
}

\begin{abstract}
Laboratory, greenhouse and field experiments were preformed to evaluate the antifungal activity of cobalt sulphate, salicylic acid, ethephone, dipotassium phosphate, ascorbic acid and neem oil at three concentrations for each against Sclerotinia sclerotiorum growth and sclerotial formation on PDA (Potato Dextrose Agar) and to verify its positive efficacy as defence activators (elicitors) in chickpea seedling and plants against damping-off and white stem rot disease. Also, efficacy of the five elicitors and neem oil in improving some growth parameters, protein, nitrogen, potassium and phosphorus contents of seed was determined.

1-Neem oil (2.5, 5.0 or $\left.7.5 \mathrm{ml} \mathrm{L}^{-1}\right)$ and salicylic acid at higher concentration $(7.5 \mathrm{mM})$ significantly reduced the fungal growth and number of sclerotial formation in vitro. Reduction was always increased by increasing concentration of neem oil.

2-Soaking seeds in each one of the five elicitors or the neem oil tested, except ethephone, decreased seedling damping-off pre- (in most cases) or postemergence and increased survivals. The most effective inducers, however, were cobalt sulphate $\left(1 \mathrm{mg} \mathrm{L}^{-1}\right)$, salicylic acid $(7.5 \mathrm{mM})$, neem oil $\left(5 \mathrm{ml} \mathrm{L}^{-1}\right)$, dipotassium phosphate $(5 \mathrm{mM})$ and ascorbic acid $(10 \mathrm{mM})$. While, ethephone treatment was the least effective. In the field experiments, white stem rot disease incidence was significantly minimized with all tessted treatments tested in both seasons, except ethephone. The highest reduction in the disease incidence was recorded with neem oil, followed by dipotassium phosphate and cobalt sulphate.

3- Giza $2 \mathrm{cv}$. was the highest susceptible to infection under greenhouse and field conditions. While, Giza195 and Giza 531 cvs. were the least.

4- Results of the field experiments indicated that application of all treatments, except ethephone, resulted in a significant improve in crop parameters of chickpea cultivars compared with the untreated control. Dipotassium phosphate recorded the highest number of tillers, weight of seed yield per plant, number of capsules per plant, and seed yield / feddan.

5- Giza 1 cultivar had the higher value of seed yield/fed. In the $1^{\text {st }}$ season, whereas Giza195 cultivar in the $2^{\text {nd }}$ season.

6- Giza 195 seeds had the higher crude protein content in the $1^{\text {st }}$ season, while Giza 531 showed the higher protein content in the $2^{\text {nd }}$ season.

7- Giza1 seeds had the higher content in phosphorus and potassium in the two seasons.

8- Ethephone exhibited the highest reduction in plant height, 100-seed weight, seed yield per feddan and N,P and $\mathrm{K}$ content in seeds..

9- Dipotassium phosphate and neem oil treatments were superior than the other in increasing values of seed yield/fed., nitrogen, protein, phosphorus, potassium contents in Giza1, and Giza 195 cvs., while the lowest of them was detected in Giza2.
\end{abstract}

Keywords: Chickpea cultivars - Sclerotinia sclerotiorum - stem rot - Inducers, Nitrogen, protein content, Phosphorus and Potassium. 
Rahmou, A. A. et al.

\section{INTRODUCTION}

Scleortinia sclerotiorum (Lib.) de Bary is an important pathogen distributed ubiquitously, attacking over 360 species of plant comprising 64 families (Purdy, 1979). Diseases caused by $S$. sclerotiorum, however, are difficult to control and may result in substantial yield losses ranged from 0 $100 \%$ (Purdy, 1979). This pathogen can stay alive in the soil for many years without its host due to formation of sclerotia (El-Morsy and Abou Zeid, 1997). In Egypt, chickpea is one of the major feed food legume crops which is attacked with white stem rot caused by S. sclerotiorum (Omar et al., 1992).

Induced resistance in plants to fungal, bacteria and viral pathogens has been demonstrated after pretreatment with a number of physical, chemical and biotic agents (Tuzun et al., 1989). The use of chemical agents has been widely studied; salicylic acid against Phytophthora infestans of potato plants (Floryszek and Wieczorek, 1993); $\mathrm{K}_{2} \mathrm{HPO}_{4} \mathrm{Or} \mathrm{K}_{3} \mathrm{PO}_{4}$ treatments against powdery mildew of cucumber (Mosa, 1997), Cobalt seed treatment of water melon against Fusarium wilt under pot and field experiments (Aly et al., 1993); ascorbic acid (10 mM) as seed soaking against damping-off of soybean (El-Blasy, 2006); neem oil as spray against gray mold of lentil (Rahhal et al., 2007).

In the challenge to fill the gap between production and consumption of protein, increasing productivity as well as cultivated area led to increasing the use of more chemical fertilizers (especially nitrogen and phosphorus), which are not only so expensive but also polluting agro ecosystems. Therefore, the current trend is to reduce the use of mineral fertilizers and keep high productivity in the meantime. Recently, some compounds as growth regulators were experimented on some crops and had remarkable responses in growth and yield. Glycolysis and tricarboxlic acid cycle as the main source of respiratory plant growth and all nutritional processes which reflect on plant growth and nutrient uptake are dependent on organic acids level in plant tissues (Givan, 1979). Ascorbic and salicylic have been synthesized in higher plant through glucose metabolism (Miernyk and Trelease, 1981 and Helsper et al., 1982). These acids are also considered as physiological relevant factor which may lead to the activity of some enzymes (Reibstein et al., 1986, Nofal et al., 1990). Hammada and El-Hakimi (2000) found that salicylic acid was more effective on carbohydrate constituent. Nasef et al.(2004) reported that applied Co showed a significantly affect on all peanut plant growth yield parameters and N,P and K uptake by forage or seeds. Sallam (1997) represented that cobalt and ethephone; IAA and kinetin increased NPK and protein contents in wheat plants. Mengel \& Kirkdy (1979) suggested that potassium phosphate as a complete soluble fertilizer was used to correct the deficiency of both $\mathrm{P}$ and $\mathrm{K}$ in soils suffered phosphate fixation or low availability. Also, many investigators observed that phosphatic fertilization induced significant increases in both seed and straw yields of lupin as well as seed protein and P contents. On the other hand, the phosphorus application did not markedly affect the protein and phosphorus contents (Hamissa and Mostafa , 1998; Bremer et al., 1989 and Abd El-Latef, 
1996). Rahhal et al. (2007) found that neem oil increased chickpea seed yield and seed contents protein, phosphorus and potassium.

This investigation was planned to study the efficacy of five different chemical inducers and neem oil on fungal growth in laboratory and incidence of white stem rot in chickpea seedlings and plants under greenhouse and field conditions and to evaluate their efficacy on seed yield and yield components.

\section{MATERIALS AND METHODS}

\section{In vitro studies:}

Efficacy of five elicitors namely; cobalt sulfate, salicylic acid, ethephone, $\mathrm{K}_{2} \mathrm{HPO}_{4}$ and ascorbic acid in addition to neem oil was determined on radial growth of $S$. sclerotiorum isolate on PDA (Potato Dextrose Agar) medium. The medium was amended with each elicitor just before solidification. The appropriate amount of each treatment, however, was prepared to mix in $50 \mathrm{ml}$ medium in each flask to give concentrations of 0.5 , 1.0 and $2.0 \mathrm{mg} \mathrm{L}^{-1}$ of cobalt sulfate; $2.5,5.0$ and $7.5 \mathrm{mM}$ of salicylic acid; 100 , 200 and $300 \mathrm{mg} \mathrm{L}$ of ethephone; $5.0,7.5$ and $10.0 \mathrm{mM}$ of dipotassium phosphate or ascorbic acid and neem oil $\left(2.5,5.0\right.$ and $7.5 \mathrm{ml} \mathrm{L}^{-1}$.). Ten $\mathrm{ml}$ of each treated PDA medium was poured in each Petri dish. Then, they were inoculated with $5 \mathrm{~mm}$ discs of the fungal growth and incubated at $20 \mathrm{C}^{\circ}$. The fungal growth was measured when radial growth in control plates reached its maximum; also the number of sclerotia was recorded.

\section{In vivo studies:-}

Seeds of chickpea varieties, Giza1, Giza2, Giza 195 and Giza 531. The were kindly obtained by legume Crop Dept., Field Crop Research Institute, ARC, Giza.

Seed soaking: Seeds $(200 \mathrm{~g})$ from each tested chickpea cultivars were soaked for 24 hrs.in $1 \mathrm{~L}$ solution of cobalt sulfate $\left(0.5,1\right.$ or $\left.2.0 \mathrm{mg} \mathrm{L}^{-1}\right)$; salicylic acid (2.5, 5.0 or $7.5 \mathrm{mM}$ ); ethephone $\left(100,200\right.$ or $\left.300 \mathrm{mg} \mathrm{L}^{-1}\right)$; dipotassium phosphate and ascorbic acid (5.0, 7.5 and $10.0 \mathrm{mM})$ and neem oil $\left(2.5,5.0\right.$ and $\left.7.5 \mathrm{ml} \mathrm{L}^{-1}\right)$.

Preparation of inoculum: The discs $(5.0 \mathrm{~mm}$ diam.) of seven day old culture of $S$. sclerotiorum isolate were placed in bottles $(500 \mathrm{ml})$ containing autoclaved sorghum grain-sand medium (75 gm sorghum grains $+25 \mathrm{gm}$ clean sand $+100 \mathrm{ml}$ sterilized water) and inculcated at $20 \stackrel{\circ}{\circ} \mathrm{C}$ for 15 days.

Pot experiment: This experiment was to assign the most effective concentration of each elicitors against plant damping off soil infestation was carried out by adding the inoculum of the fungus to the past containg the formalin-sterilized soil at the rate of $5 \%$ soil weight $(\mathrm{w} / \mathrm{w})$. Pots were watered every other day for one week before planting. The same amount of autoclaved sand sorghum mixture was added to the pots as a chek treatment. Five seeds of chickpea Giza1, Giza2, Giza195 and Giza531 treated with the chemical inducers and neem oil were sown in pots $(20 \mathrm{~cm}$ in diam) and four pots were used for each treatment. Seeds of untreated control were soaked in tap water for the same time period. Pre-, post-emergence damping-off and survival plants were recorded after 15,45 , and 75 days after planting (DAP). 
Rahmou, A. A. et al.

Table(1): Chemical structures formula of the used elicitors and their concentratios used the pot experiment

\begin{tabular}{|l|l|l|l|}
\hline \multicolumn{1}{|c|}{ Treatments } & \multicolumn{1}{|c|}{$\begin{array}{c}\text { Chemical } \\
\text { structure }\end{array}$} & $\begin{array}{c}\text { Molecul } \\
\text { ar } \\
\text { weight }\end{array}$ & \multicolumn{1}{|c|}{ Concentrations } \\
\hline Cobalt sulfate & $\mathrm{CoSO}_{4} .7 \mathrm{H}_{2} \mathrm{O}$ & 281.1 & $0.5,1.0$ and $2.0 \mathrm{mg} \mathrm{L}^{-1}$ \\
Salicylic acid & $\mathrm{C}_{7} \mathrm{H}_{6} \mathrm{O}_{3}$ & 138.1 & $2.5,5.0$ and $7.5 \mathrm{mM}^{-1}$ \\
Ethephon & $2-c h l o r o e t h y l$ phosphonic & 144.5 & 100,200 and $300 \mathrm{mg} \mathrm{L}^{-1}$ \\
Dipotassium & acid & 174.2 & $5.0,7.5$ and $10.0 \mathrm{mM}^{-1}$ \\
phosphate & $\mathrm{K}_{2} \mathrm{HPO}_{4}$ & 176.1 & $5.0,7.5$ and $10.0 \mathrm{mM}^{-1}$ \\
Ascorbic acid & $\mathrm{C}_{6} \mathrm{H}_{8} \mathrm{O}_{6}$ & -- & $2.5,5.0$ and $10.0 \mathrm{ml} \mathrm{L}^{-1}$ \\
Neem oil & Commercial oil & & \\
\hline
\end{tabular}

Field experiments:

Experiments were carried out at Etay El-Baroud Agrc. Res. Station, Behira, governorate during the two successive seasons (2004/05 \& 2005/06) to evaluate the efficacy of five chemical inducers and neem oil effective at the most concentrations on controlling chickpea white stem rot disease under natural conditions and productivity of chickpea cultivars (Giza1, 2,195 \& 531).

Soil analysis: Soil samples were taken from the soil surface layer of the farm (0-30 cm depth) before planting for physical and chemical analyses according to Black (1965). The results of soil analysis are shown in Table (2).

Table (2): Physical and chemical analysis of the field soil.

\begin{tabular}{|c|c|c|c|c|c|c|c|c|c|c|}
\hline \multirow{2}{*}{ Seasons } & \multirow{2}{*}{$\begin{array}{c}\text { Organic } \\
\text { matter } \\
(\%)\end{array}$} & \multirow{2}{*}{$\begin{array}{c}\mathrm{CaCO}_{3} \\
(\%)\end{array}$} & \multicolumn{4}{|c|}{$\begin{array}{l}\text { Particle size distribution } \\
(\%)\end{array}$} & \multirow{2}{*}{$\begin{array}{l}\text { Soil } \\
\text { texture }\end{array}$} & \multicolumn{3}{|c|}{$\begin{array}{c}\text { Available } \\
\text { nutrients } \\
\text { mg kg }^{-1}\end{array}$} \\
\hline & & & $\begin{array}{c}\text { Coarse } \\
\text { sand }\end{array}$ & $\begin{array}{l}\text { Fine } \\
\text { sand }\end{array}$ & Silt & Clay & & $\mathbf{N}$ & $\mathbf{P}$ & K \\
\hline $2004 / 05$ & 1.32 & 3.84 & 11.30 & 9.50 & 39.00 & 40.20 & Clayey & 58 & 8 & 323 \\
\hline $2005 / 06$ & 1.39 & 3.74 & 11.14 & 9.66 & 38.58 & 40.62 & Clayey & 73 & 5 & 255 \\
\hline \multicolumn{11}{|c|}{ Soluble cations and anions( $\mathrm{meq}^{-1}$ ) } \\
\hline Seasons & $\begin{array}{c}\mathrm{pH} \\
1: 2.5 \\
\text { soil: } \\
\text { water }\end{array}$ & $\begin{array}{c}\text { EC, } \\
\text { dS/m } \\
1: 5 \\
\text { soil: } \\
\text { water }\end{array}$ & $\mathrm{Ca}^{++}$ & Mg++ & $\mathrm{Na}^{+}$ & $\mathrm{K}^{+}$ & $\mathrm{CO}_{3}^{--}$ & $\mathrm{HCO}_{3}^{-}$ & $\mathrm{Cl}^{-}$ & $\mathrm{SO}_{4}=$ \\
\hline $2004 / 05$ & 7.94 & 0.59 & 1.09 & 0.87 & 1.08 & 0.23 & - & 0.48 & 0.47 & 2.31 \\
\hline $2005 / 06$ & 8.03 & 0.71 & 0.89 & 0.82 & 1.05 & 0.21 & - & 0.43 & 0.45 & 2.09 \\
\hline
\end{tabular}

Experimental design: The experimental layout was split plot design with 3 replicates, where the varieties were allocated in the main plots and the treatments occupied sub plots. The area of each plot was $7.2 \mathrm{~m}^{2}$ consisting of 4 ridges of $3 \mathrm{~m}$ in length and $0.60 \mathrm{~m}$ in between.

Treatments:The used concentrations of the chemical inducers for the field trail were cobalt sulphate $1 \mathrm{mg} \mathrm{L}^{-1}$; salicylic acid $7.5 \mathrm{mM}$; ethephone $300 \mathrm{mg}$ $\mathrm{L}^{-1}$; neem oil $5.0 \mathrm{ml} / \mathrm{L} ; \mathrm{K}_{2} \mathrm{HPO}_{4} 5.0 \mathrm{mM}$ and ascorbic acid $10.0 \mathrm{mM}$ were used in the field experiment. These concentration were found be the most effective from the pot experiment. 
Seeds of chickpea cultivars were soaked in each solution of inducers and neem oil at the above mentioned concentration for 24 hours and left for one day to dry before planting and then sowing in hill of $10 \mathrm{~cm}$ apart in two sides/ridge with two seeds/hill. Seeds of untreated control were soaked in tap water for the same period before planting.

Fertilization: Primary additions of N, P and $\mathrm{K}$ fertilizers were practiced as soil application for all plots. Nitrogen was added at the rate of $15 \mathrm{~kg} \mathrm{~N} / \mathrm{fed}$. as ammonium sulphate $(20.6 \% \mathrm{~N})$ after 15 days from sowing. Phosphorus at rate of $30 \mathrm{~kg} \mathrm{P} \mathrm{P}_{2} / \mathrm{fed}$ as superphosphate $\left(15 \% \mathrm{P}_{2} \mathrm{O}_{5}\right)$ and potassium at the rate of $24 \mathrm{~kg} \mathrm{~K} 2 \mathrm{O} / \mathrm{fed}$. as potassium sulphate $\left(48 \% \mathrm{~K}_{2} \mathrm{O}\right)$ were added at sowing.

Disease assessment: Disease incidence of stem rot was recorded 90 and 120 days after sowing according to the method of Purdy (1979).

Yield and yield component: At harvest, two ridges from each plot were taken at random and the following growth characters were recorded: plant height $(\mathrm{cm})$, no. of branches/plant, weight of 100 seeds $(\mathrm{g})$, capsule number / plant and seed yield ( $\mathrm{kg} / \mathrm{fed}$ ).

Analysis of seeds: Composite seed samples were taken in order to be dried at $70 \mathrm{C}^{\circ}$ and ground then $0.5 \mathrm{~g}$ was subjected to wet ashing. Aliquots were taken for $\mathrm{N}$ determinate using the micro-Kjeldahl method as described by A.O.A.C. (2000). The $\mathrm{N}$ content was multiplied by 6.25 to obtained protein percentage. Phosphorus was determined calorimetrically and potassium was estimated by flam photometer according to Jackson (1973). Data were also statistically analyzed according to Snedecor and Cochran (1981).

\section{RESULTS}

\section{I- In vitro studies:}

Data in Table (3) show that the fungal linear growth was significantly reduced with only the high concentration $(7.5 \mathrm{mM})$ of salicylic acid and $7.5 \mathrm{ml}$ $\mathrm{L}^{-1}$ of neem oil, among the five inducers tested. However, efficacy of neem oil was significantly higher than that of salicylic acid. Generally, the three concentrations of neem oil reduced the fungal linear growth significantly than the control or the other tested treatments. On the other hand, the high concentration of salicylic acid and the three of ones of neem oil were the most effective treatments in reducing number of sclterotia/plate compared with the control, and the reduction was significant.

\section{In vivo studies:}

\section{1- Greenhouse experiments:}

Data in Table (4) show that a significant decrease of pre-emergence damping-off below that of the control resulted when the seeds were soaked in cobalt sulphate (1.0 and $2.0 \mathrm{mg} \mathrm{L}^{-1}$; salicylic acid (5.0 and $\left.7.5 \mathrm{mM}\right)$; neem oil $\left(2.5,5.0\right.$ and $\left.7.5 \mathrm{ml} \mathrm{L}^{-1}\right) ; \mathrm{K}_{2} \mathrm{HPO}_{4}(5.0$ and $7.5 \mathrm{mM})$ and ascorbic acid (10.0 $\mathrm{mM})$. Only, soaking in ethephone significantly increased percentage of preemergence damping-off, than the control of Giza 1, Giza 195 and Giza 531. 
Rahmou, A. A. et al.

Table (3): Effect of chemical inducers and neem oil at different concentrations on linear growth and number of the fungal sclerotia in vitro:

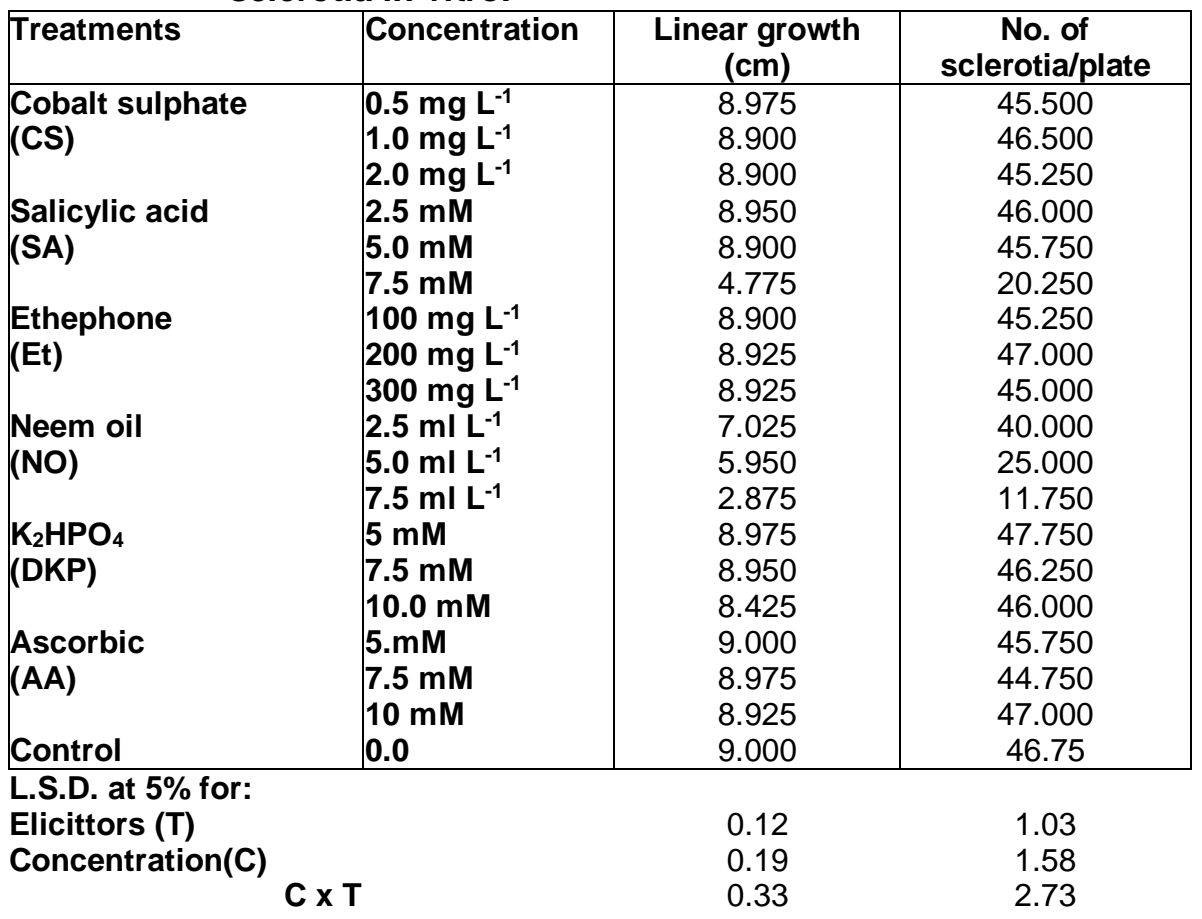

A significant reduction in post-emergence damping-off was obtained when seeds were soaked in solution either of cobalt sulphate $(0.5,1.0$ and $\left.2.0 \mathrm{mg} \mathrm{L}^{-1}\right)$; salicylic acid $(2.5,5.0$ and $7.5 \mathrm{mM})$, neem oil $(2.5,5.0$ and $7.5 \mathrm{ml}$ $\left.\mathrm{L}^{-1}\right) ; \mathrm{K}_{2} \mathrm{HPO}_{4}(5.0,7.5$ and $10.0 \mathrm{mM})$ and ascorbic acid (5.0, 7.5 and $\left.10.0 \mathrm{mM}\right)$ in case of Giza1 cultivar.

As for ethephone, it gave increase or equal percentage of postemergences, except in Giza 195 at $100 \mathrm{mg} \mathrm{L}^{-1}$ since it caused significant decrease compared with the control. Taking survival plants into consideration, the highest percentages were obtained from cobalt sulphate treatment (1.0 mg L-1); salicylic acid $(7.5 \mathrm{mM})$; neem oil $\left(5.0 \mathrm{ml} \mathrm{L}^{-1}\right) ; \mathrm{K}_{2} \mathrm{HPO}_{4}$ $(5.0 \mathrm{mM})$ and ascorbic acid at $(10.0 \mathrm{mM})$ where the percentages were significantly higher than the control of four chickpea cultivars tested with no significant differences among them. So, these concentrations of the used inducers were applied in the field experiment. 
J. Agric. Sci. Mansoura Univ., 34 (1), January, 2009

4

685 
2- Field experiment:

\subsection{White stem rot disease:}

Chemical inducers ,i.e. CS, SA, Et, DKP, AA and NO at the concentrations of $1 \mathrm{mg} \mathrm{L}^{-1}, 7.5 \mathrm{mM}, 300 \mathrm{mg} \mathrm{L}^{-1}, 5 \mathrm{mg} \mathrm{L}^{-1}, 10.0 \mathrm{mM}$ and $5 \mathrm{~m}$ $\mathrm{L}^{-1}$ respectively were used in the field experiment since in the application in the pot experiment resulted in the highest percent of survival plants. Data in Table (5) showed that in the first season, dipotassium phosphate as seed soaking ranked as the most effective treatment to control whit stem rot diseasefollowed by neem oil, cobalt sulphate and salicylic acid, respectively while cobalt sulphate, $\mathrm{K}_{2} \mathrm{HPO}_{4}$, salicylic acid and neem oil occupied the first four ranks in second season exhibiting effectiveness over the untreated control. These results confirm the role of $\mathrm{K}$ to increase the plant ability to resist Fungal and bacterial deseases. Ascorbic acid and ethephone, however, were the least effective chemical inducers in both growing seasons. Data also show that mean percentages of stem rot on Giza1 and Giza2 plants were greater than the other cultivars tested, while Giza 531 exhibited less infection (\%).(Table 5).

In general, dipotassium phosphate and neem oil were the most effective treatments for all cultivars used followed by cobalt sulphate and salicylic acid, except Giza 195 cultivar, while ethephone was less effective treatment in decreasing disease incidence in all cases, showing that $\mathrm{K}$ nutrient had a predominating influence on resistance to white stem rot disease.

2.2. Plant height: In most cases, the height of chickpea plant was decreased by all inducers and neem oil treatments as seed soaking treatments as compared with the control in the $1^{\text {st }}$ season in case of all cultivars (Table, 6). On contrary, plant height was significantly higher with cobalt sulphate, $\mathrm{K}_{2} \mathrm{HPO}_{4}$ and ascorbic acid in the $2^{\text {nd }}$ season over the control. Ethephone treatment in both seasons, however, gave the shortest plants among the other treatments.

2.3. Number of tillers per plant: All chemical inducers and neem oil (Table, 6) gave significant increase in number of tillers over the control in both growing seasons. No significant differences were observed among the four cultivars tested. $\mathrm{K}_{2} \mathrm{HPO}_{4}$ and ascorbic acid were the best treatments in increasing number of tillers in both seasons, while cobalt sulphate treatment was the less effective if compared with the other treatments.

2.4. Weight of $\mathbf{1 0 0}$ seeds $(\mathbf{g})$ : Data in Table (7) show that in the $1^{\text {st }}$ season no significant differences between the treatments tested on weight of 100 seeds in the $1^{\text {st }}$ season. At the same time, there is no significant difference between cultivars in $100 \mathrm{~g}$ seeds weight. While, in the $2^{\text {nd }}$ season, there is a significant difference between the substances tested in increasing seed index. Neem oil, ascorbic acid and salicylic acid were the most effective inducers, while ethephone was the least affective if compared with the control.

2.5. Dry weight/plant: All chemical inducers and neem oil (Table,7) except ethephone treatment, significantly, increased dry weight per plant over the control. $\mathrm{K}_{2} \mathrm{HPO}_{4}$ followed by cobalt sulphate and ascorbic acid were effective treatments in increasing dry weight of chickpea plant. 
J. Agric. Sci. Mansoura Univ., 34 (1), January, 2009

5 
Rahmou, A. A. et al.

6

688 
J. Agric. Sci. Mansoura Univ., 34 (1), January, 2009

7

689 
On the other hand, all treatments significantly increased dry weight of plant compared with the control. The most effective treatments was cobalt sulphate followed by ascorbic acid and salicylic acid. The worst treatment in this respect, however, was ethephone.

2.6. Seed weight plant: $\mathrm{K}_{2} \mathrm{HPO}_{4}$ treatment gave the highest seed weight among the tested treatments in two successive growing seasons (Table, 8). In the two experimental seasons, significant increases in seed weight for all treatments were recorded. Differences between Giza1 and G.195 were not significant in both trial seasons.

2.7. Number of capsules/plant: All treatments (Table, 8) gave significant increases in number of capsules per plant, except ethephone, compared with the control in the two growing seasons. In these respect, seed soaking with $\mathrm{K}_{2} \mathrm{HPO}_{4}$ followed by neem oil were the most effective in increasing number of capsules over the other treatments. Whereas, ethephone treatment gave the least no. of capsules per plant and caused a significant decrease when compared with the control. On contrast, $\mathrm{K}_{2} \mathrm{HPO}_{4}$ treatment was the best in increasing no. of capsules per plant compared with the other treatments on the cultivars tested.

2.8. Seed yield feddan (kg): Data presented in Table (9) show that all inducers and neem oil, except ethephone treatment, significantly increased seed yield of feddan over the untreated control in both seasons. However, $\mathrm{K}_{2} \mathrm{HPO}_{4}$ treatment was superior in increasing seed yield for all cultivars (Giza1, Giza 195, Giza 531 and Giza2) in both trial seasons, followed by neem oil that gave the highest seed yield of Giza 1 in $1^{\text {st }}$ season and G.195 in the $2^{\text {nd }}$ season. Ethephone was the least effective if compared with the other treatments on the tested cultivars, since it caused significant reduction in seed yield of the tested cultivars compared to the controls.

\subsection{Protein content and removal $\mathrm{N}, \mathrm{P}$ and $\mathrm{K}$ by seeds:}

\section{A. Nitrogen content:}

Data in Table (10) indicate that nitrogen content has considerably varied in the tested cultivars in the produced seeds from the five inducers or neem oil. The seeds of Giza1 produced from $\mathrm{K}_{2} \mathrm{HPO}_{4}$ and neem oil treatments contained the highest seed nitrogen amount during the both seasons, meanwhile the lowest nitrogen amount was detected in Giza2. Ethephone treatment, however, exhibited the lowest amount of nitrogen in the all tested cultivar seeds in both seasons.

\section{B. Protein content:}

The chickpea cultivars were significantly variable in their seed protein content (Table, 10). The highest seed protein was produced by Giza1 in second season. Meanwhile, the lowest protein content was detected in Giza2. In general, the higher protein content was recorded with $\mathrm{K}_{2} \mathrm{HPO}_{4}$ and neem oil treatments in all cultivar seeds. On contrary, the ethephone treatment exhibited the lowest protein amount.

\section{Phosphorus content:}

Phosphorus content was higher in seeds of all chickpea cultivars treated with each of all chemical inducers and neem oil as seed soaking, except ethephone (Table, 11). 
J. Agric. Sci. Mansoura Univ., 34 (1), January, 2009

8 
Rahmou, A. A. et al.

9

692 
J. Agric. Sci. Mansoura Univ., 34 (1), January, 2009

10

693 
Rahmou, A. A. et al.

11

694 
Phosphorus content was mostly significantly and higher in seeds treated with $\mathrm{K}_{2} \mathrm{HPO}_{4}$ or neem oil, followed by cobalt sulphate, salicylic acid and ascorbic acid in all cultivar seeds. Significant increases over the control were obtained with cobalt sulphate and salicylic acid treatments in seeds of Giza 2 and Giza 531. Also, significant increase over the control were obtained with ascorbic acid and salicylic acid treatments in seeds of Giza1. Salicylic acid treatment ,however, was the third superior treatment after $\mathrm{K}_{2} \mathrm{HPO}_{4}$ and neem oil treatments in seeds of Giza195. On the other hand, soaking seeds in ethephone for all chickpea cultivars tested caused a significant decrease in phosphorus content than the control treatment in the two seasons.

\section{Potassium content:}

In general, the amount of potassium content was higher in seeds of all chickpea cultivars treated with each of chemical inducers and neem oil, except with ethephone(Table, 11). The highest amount of potassium content was detected in Giza1 using $\mathrm{K}_{2} \mathrm{HPO}_{4}$ and neem oil treatments in the second season, followed by Giza 195. The lowest amount was detected in Giza2 and the potassium amount in seeds of ethephone treatment was significantly lower than the other treatments and control.

\section{DISCUSSION}

Sclertinia sclerotiorum (Lib.) de Bary, the causal fungal organism of stem rot disease, is considered a serious disease that attacks legume crops, forage and vegetable in Egypt. The impact of the disease was increased notably during the last decade causing a remarkable yield losses (Omar et al., 1992 and Mazen 1995).

$S$. sclerotiorum is among the most non specific omnivorous, and successful of plant pathogen. Plants susceptible to infection by this pathogen encompass 64 families, 225 genera and 361 species (Purdy, 1979). Moreover, this fungus is geographically cosmopolitan and has a broad ecological distribution including the four different chickpea cultivars which were evaluated under greenhouse and field conditions to infect by stem rot disease. Giza 2 cultivar, however, was the highly infected by $S$. sclerotiorum under greenhouse and field conditions, while Giza 531 was the least susceptible. These results are in agreement with the results obtained by El-Blasy (2006).

Significant reduction in the disease incidence was obtained as a result of resistance induced by soaking seeds of susceptible chickpea cultivars in one of the five elicitors tested. Data obtained here supports those previously mentioned by several authors ( Yurina et al., 1993).

However, dipotassium phosphate was more effective in decreasing the disease incidence than the other elicitors used, either under soil contamination with the pathogen in greenhouse or with natural infection under field conditions. The obtained results coincide with Abd-El-Kareem (1998).

On the other hand, neem oil was found to be the second effective treatment after dispotassium phosphate as controlling stem rot disease. This 
result is in complete agreement with the finding of Rahhal et al. (2007). Soaking seeds in cobalt sulphate suspension significantly reduced chickpea stem rot. In this respect different cobalt concentrations were previously used as an effective treatment in inducing resistance against numerous plant diseases (Sallam, 1997).

Contrary to the result of Ibrahim (1993) and Abd El-Kareem,(1998), ethephone treatment exhibited increasing in damping-off and stem rot disease and decrease total seed yield and another growth parameters, this result is not agreement with Ibrahim,(1993). This may be attributed to the low concentration.

Under field conditions, the affirmable treatment except ethephone showed remarkable increase in crop parameters including number of tillers, seed yield/ plant, number of capsule/ plant and seed yield per feddan and weight of 100 seeds compared with untreated control. The increase in yield was not only due to the reduction in disease incidence, but also due to a positive effect of the treatments than themselves (Abd El-Kareem, 1998). In this respect, treatment with cobalt sulphate increased significantly most of yield component, seed yield, and protein content and removed N,P and K by seeds. It is thought to be a regulatory element affecting some plant process such as $\mathrm{N}$-fixation and vitamin $\mathrm{B}_{12}$ accumulations (Ahmed and Evans, 1959). These results are in agreement with those obtained by Youssef et al.(2001) who attributed to the effect of Cobalt on increasing plant of studied elements to the Cobalt stimulating effect on growth, since Cobalt is involved in Cobaltenzyme and hence is essential for several enzymatic reaction. Nasef et al. (2004) showed that the growth, yield component and uptake of N, P, K of peanut increased significantly with increasing the applied Co for surface, foliar and coating application.

Application of salicylic acid, neem oil and ascorbic acid increased significantly most of yield component, seed yield, and protein content and removed N,P and K. In this respect, Genaidy et al.(1995) found good response in growth and yield of some main field crop plants as a result of foliar application of some organic acids such as ascorbic and citric. Also ,Hammada and El-Hakimi, (2000) reported that the foliar application of salicylic acid was more effective on carbohydrate constituent. However, the promotive effect of ascorbic acid could be attributed to its effect on metabolic and physiological processes as well as increasing the organic acids exerted from the root into the soil, consequently increasing the solubility of most nutrients which slowly release into the rhizosphere zone where it may be utilized by the plant. These results are in harmony with those reported by Zahran (1993), Negm et al.(1996) and Nassar \& Ismail (1999). Abd El-Magid et al.(2004) found that the application of salicylic acid gave significant increases of root and growth of sugar beat plants as compared to the control. As for N, P and K contents of seeds, Negm et al.(1996) stated that ascorbic acid had no significant effect on the content of protein, $\mathrm{P}$ and $\mathrm{K}$ in lentil seeds. In the respect of neem oil, Rahhal et al.(2007) found that neem oil increased yield component, seed yield, crude protein, phosphorus and potassium content for seed lentil. 
The highest yield component, seed yield, protein and removal of N,P and $\mathrm{K}$ was recorded with dipotassium phosphate. It corrected directly $\mathrm{P}$ and $\mathrm{K}$ deficiencies and indirectly by the nutrition balance in plants. The present results are in agreement with those found by (Sparks, 1986) on foliate peanut, (Hassaballa et al., 1991) on citrus and (Hamida et al., 2000) on maize. Abou-Zeid et al.(2005) found that foliar application of $\mathrm{KH}_{2} \mathrm{PO}_{4}$ increased fresh yield, dry yield and N,P and $\mathrm{K}$ uptake by clover plants. Regarding $\mathrm{KH}_{2} \mathrm{PO}_{4}$ foliation effect on increasing $\mathrm{N}$ content by plant. Sparks (1986) and Hassaballa et al.(1991) attributed that effect to correction of the nutritional balance in plant. The increases in $\mathrm{P}$ content by $\mathrm{KH}_{2} \mathrm{PO}_{4}$ are in agreement with the results obtained by Hassaballa et al.,(1991) and Hamdia et al.,(2000).

Contrary to the result of ethephone treatment, it exhibited significant reduction in plant height, number of branches/plant, number of pods/plant, number of seeds per pod, weight of 100 seed, seed yield, protein and removal N,P and K in seeds. This result is similar to those found by Salem et al.(1994) on faba bean.

The highest seed yield of Giza1 and Giza 195 might be due to its large seed size and at the same time, its larg vegetative growth reflected on synthesis and building metabolites and these two seasons caused the seed high levels from protein and nitrogen, phosphorus, potassium contents. Such variations in characters between cultivars might be reflected by the deficiency of the plant in building metabolites or might be ascribed to the gentical differences. Also, data show that there are significantly differences between the cultivars tested in plant growth and yield component. These results are in harmony with findings of Mokhtar (1993), Magawer (1990) Rahmou and Zidan (2006) on chickpea and Rahhal et al.,(2007) on lentil.

\section{REFERENCES}

A.O.A.C.(2000). Official methods of analysis, association of official analytical chemist $\left(17^{\text {th }}\right.$ ed), Gaithersburg, Maryland USA.

Abd-El-Kareem, E. I. (1998). Induction of resistance to some diseases of cucumber plants grown under greenhouse conditions. Ph.D. Thesis, Fac. of Agric. Ain Shams Univ., 1:117

Abd El-Latef, E.M.(1996). Mungbean (Vugna radiate L-Wilczek) yield response to foliar application of nitrogen and potassium under different levels of phosphatic fertilization. Abs. $7^{\text {th }}$ Conf. Agron., Mansoura Univ., Egypt. Sep., pp 45.

Abd El-Magid, A. A.; B. M. Abou El-Magd and H.G. Abu El-Fatah (2004). Using organic compounds for improving sugar beet productivity. $\mathrm{J}$. Agric. Sci. Mansoura Univ., 29(3):1551-1561.

Abou-Zeid, M.Y.; R.N.Zaki and M.A. Negm (2005). Effect of bacterial inoculation and spraying with $\mathrm{K}_{2} \mathrm{HPO}_{4}$ on Egyptian clover in a calcareous soil. Egypt.J. Soil Sci., 45,(2) pp: 209-224. 
Ahmed, B.B and H.G. Evans (1959). Effect of Co on the growth of soybean in the absence of supplied nitrogen. Biochem. and Biophys. Res. Comm.,1:271.

Aly, M. M.; W. E. Ashour; M. M. Diab and F. Abdel-Kareem (1993). Induced resistance to Fusarium wilt of watermelon under field conditions. $5^{\text {th }}$ Nat.Conf.of Pests and Dis.of Veg. and Fruits in Egypt, Ismailia, PP:414-445.

Black, C.A.(1965). "Methods of Soil Analysis" American Society of Agronomy Midison Wisconsin, U.S.A.

Bremer, E.C.:Van Kessel and R. Karamanos (1989). Inoculant phosphorus and nitrogen responses of lentil. Can .J .Plant Sci., 69:691-701.

El-Blasy, S.A.S. (2006). Studies on stem rot disease in chickpea. M.Sc. Thesis, Fac., Agric. Suez Canal Univ., 114.

El-Morsy, G.A. and N.M. Abou-Zeid (1997). Survey of Sclerotinia stem rot disease in north Egypt. ICARDA $9^{\text {th }}$ Annual Coordination Meeting Cairo.

Floryszek, K. and J. Wieczorek (1993). Induced systemic resistance on the potato leaves to Phytophthora infestens. Phytopathologia-Polonica, 18:39-44 (c.f. Data Base of CAB International)

Genaidy, S. A.; A. A. Abd El-Magid and M.H.Hegazy (1995). Effect of some organic acids in relation to some mineral fertilizers for production of some main field crops. Egypt., J. Appl. Sci.,10(5):835-846.

Givan, G.V. (1979). Metabolic detoxification of ammonia in tissues of higher plants. Phytochemistry, 18:375-382.

Hamdia, M. A.; H.M. A. El-Komy and N. Barakat, (2000). The rate of foliar phosphorus and potassium fertilization and/or Azospirillum lipoferum or Bacillus polymxa inoculation in nitrogen fixation (NIS) and mineral nutrition of maize grown under salt stress. Inter. Colloquium For the Optimization of Plant Nutrition. Cairo, Egypt, April 8-13: Session (13).

Hamissa, M.R. and A.T.Mostafa (1998). Fertilizer management practices for wheat using tracer technique for nitrogen and phosphorus. Adv. Agric. Res. Egypt., 1(1):23-64.

Hammada, A.H. and A.M.A.El-Hakimi (2000). Salicylic acid versus salinitydrought-induced stress on wheat seeding. Ix International Colloquium For the Optimization of Plant Nutrition. April, 8-13, Cairo Sheraton, Cairo-Egypt.

Hassaballa, I.A.; M.M. Sharaf ; R.N. Komb and M.D. El-Deeb (1991). Effect of foliar $\mathrm{K}$ and $\mathrm{P}$ fertilization on growth, yield and mineral content of citrus grown in different localities. Desert Inst. Bull, A.R.E.,41(2):323.

Helsper, J. P; L. Kagan; C. L. Hilby; J.M.Maynard and F.A.Loewas (1982). Ascorbic acid biosynthesis in ochromonas danica. Plant Phsiol., 69:465-468.

Ibrahim, K. F. (1993). Induced resistance in watermelon (Citrus vulgaris) against with disease caused by Fusarium xysporum f.sp nirum. M.Sc. Thesis, Fac. of Agric. Ain Shams University.

Jakson, M.L.( 1973). "Soil Chemical Analysis" Prentic-Hall of Indian Private Limited New Delhi. 
Magawer, Erran A. (1990). Effect of sowing data and harvesting time on some promising lines of chickpea (Cicer aretinum L.) M.Sc. Thesis, Fac. of Agric. Fayoum, Cairo Univ., Egypt.

Mazen, M. M. (1995). Pathological studies on Sclerotinina sclerotiorum affecting some legume crops. M.Sc. Thesis, Cairo Univ., Egypt.

Mengel, K. and E.A. Kirkdy (1979)."Principals of Plant Nutrition". Inter. Potash Inst., Bern, Switzerland.

Miernyk, J. A. and R. N. Trelease (1981). Role of malate synthase in citric acid synthesis by maturing cotton embryos: A proposal. Plant Physiol., 68:875-881.

Mokhtar, Soheir, A. Z. M.(1993). Study on yield attributes interrelationship and path analysis in several large and small seeded promising chickpea lines (Cicer aretinum L.) MSc. Thesis, Fac. of Agric. Ain Shams Univ., Egypt.

Mosa, A. A. (1997). Effect of foliar application of phosphates on cucumber powdery mildew. Ann. of Agric. Sci., 42:241-255.

Nasef, M. A.; A. M. Abdel El-Hameed; H. M. Salem and Amal F. Abd ElHamide (2004). Efficiency of applied rates and methods of cobalt on growth yield and elemental composition of peanut plants grows on a sandy soil. Annals of Agric. Sci., Moshtohor., 42(2):851-860.

Nassar, K. E. and K.M. Ismail (1999). Effect of ascorbic acid and phosphorus application on lupin yield (Liupinus termis L.) grown on sandy soil. Egypt. J. Appl. Sci., 14(10):357-368.

Negm, A. Y.; F. A. Zahran and N.S.Rizk (1996). Foliar application of ascorbic acid, magnesium and nickel to lentil plants grown in newly reclaimed soils. Annals of Agric. Sci. Moshtohor, 34(4):2015-2024.

Nofal, M,A.; M. H. Rabie, K. M. Khalil and A. F. Mohamed (1990). Growth and some micronutrient content of lettace plants as applied by seed soaking and foliar spray of ascorbic and citric acids. Proc. of Soil Fertility and Foliar Fertilization Conf., Giza, Egypt,14-15

Omar, S. A.; S. M. El-Gantiry and A. M. Khattab (1992). Screening chickpea lines and cultivars for resistance to root rot and wilt and evaluating some seed protecting to control Sclerotinia stem rot and root rot. ICARDA, $4^{\text {th }}$ Ann. Meting, Cairo, 13-18 Sept.

Purdy, L. H.(1979). Sclerotinia sclerotiorum: history disease , symptomatology, host range geographic distribution and impact. Phytophathology, 69:875-880.

Rahhal, M. M .H.; I. A. Ismail and A. A. Rahmou (2007). Efficacy of repeated spray of neem oil for control of gray mold disease of lentil plants caused by Botrytis cinerea and on some of the chemical component of lentil seeds. J. Pest Cont.\&Environ Sci.,15, (1):43-67.

Rahmou, A. A. and E. A. Zidan (2006). Statistical analysis and economical evaluation of some chickpea cultivars response to potassium fertilization. Minufiya J. Agric. Res. Vol.31No.6:1565-1585.

Reibstein, D.; J.A.Holander; S.J.Pilikis and S.G.Shulman (1986). Studies on the regulation of yeast phosphofructo-1-Kinase: It's role in aerobic and anaerobic glycolysis. Biochemistry, 25:219-227. 
Salem, Dorreiah E., S. A. M. Omar and M.M.Aly (1994). Induction of resistance in faba bean against chocolate spot and rust diseases using ethephone seed treatment. FABIS.

Sallam, Minaas, El-Syaed (1997). Studies on leaf vust of wheat in Egypt. Ph.D. Thesis, Fac. of Agric., Zagazig Univ.

Snedecor, G. W. and W. G. Cochran (1981). Statistical Methods, Seventh Edition, lowa State Univ. Ames, lowa, USA.

Sparks, D. (1986). Growth and nutrition of peanut seedlings from potassium phosphate foliar sprys. Hort science 21(31-7): (c.f.Soils and Fert. 50, (2738).

Tuzun, S.; M. N. Rao; V. Vogeli; C.L. Schard and J.Kuc (1989). Induced systemic resistance to blue mould: Early induction and accumulation of $\mathrm{P}-1,3$ glucanase, chitinase and other pathogensis proteins (b-proteins in immunized tobacco. Phytopathology, 79:979-983.

Youssef, R.A.; Nadia Gad and F. Anter (2001). Studies on the behavior of cobalt in the rhizosphere of tomato seedling. 1-changes in $\mathrm{pH}$ in relation to Co. distribution across the rhizosphere. Egypt. J. Soil Sci., $41(1-2) 123$.

Yurina, T.P.; V. A. Karavaev and M. K. Solntsev (1993). Characteristics of metabolism in two cucumber cultivars with different resistance to powdery mildew. Russian Plant Physiol., 40:197-202.

Zahran, F.A. (1993). Studies on fertilization on lentil. Ph.D Thesis,Fac. Agric., Al-Azhar Univ., Cairo, Egypt.

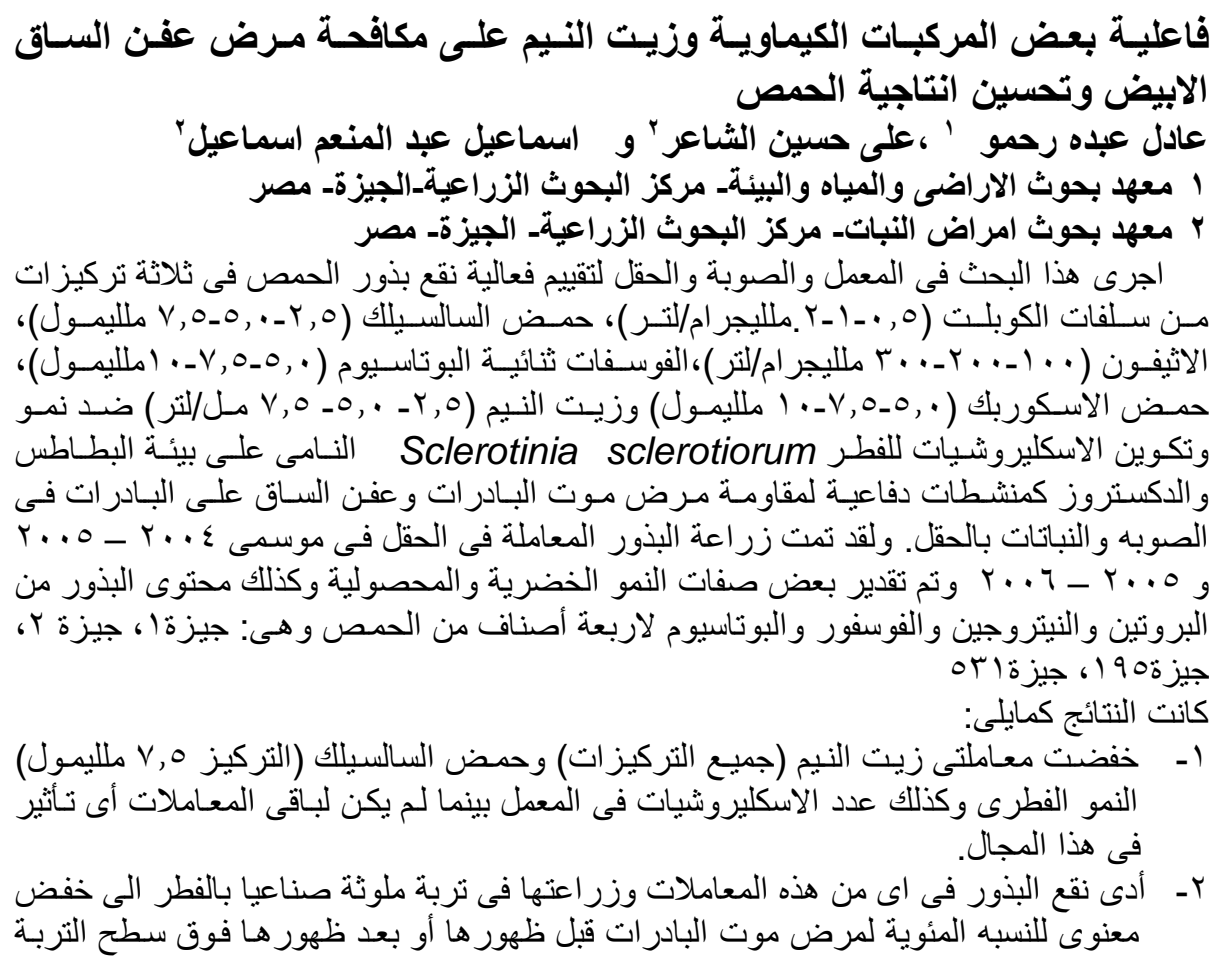




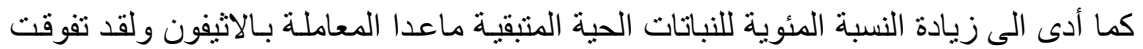

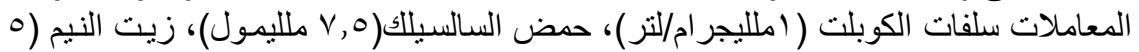

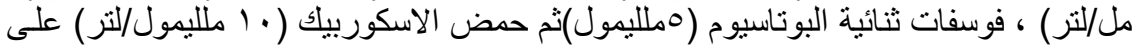

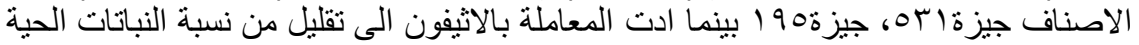

المنبقية.

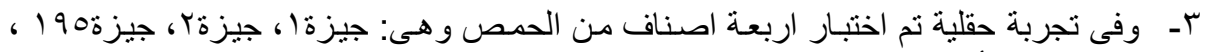

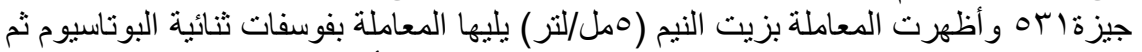

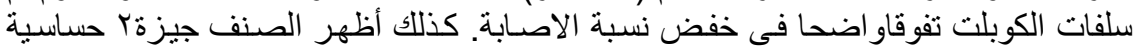

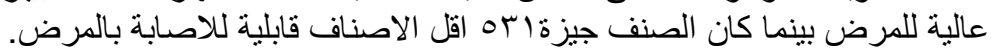

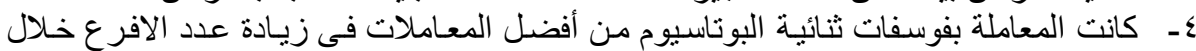

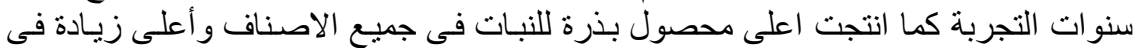

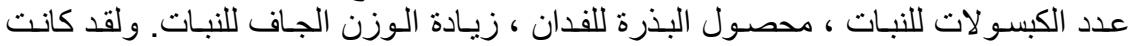

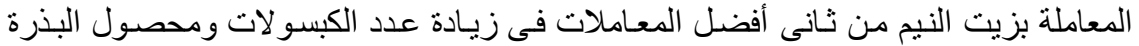
للفدان. 0ـ حقق صنف جيزةا أعلى قيمة فى محصول البذرة/فدان فى السنة الاولى، وصنف جيزة 190 فى السنة الثانية.

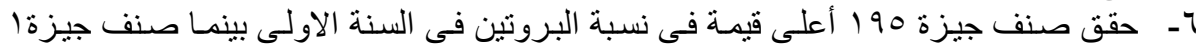

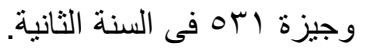

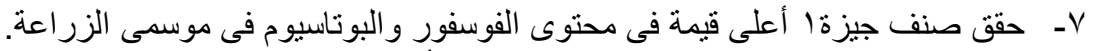

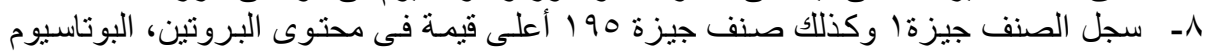

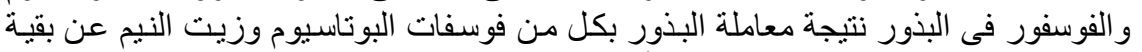

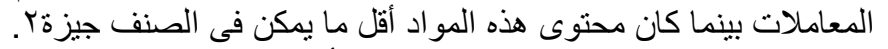

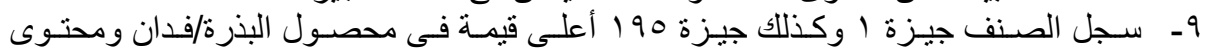
النيتروجين و الفوسفور و البوتاسيوم في البذرة. 
Rahmou, A. A. et al. 
J. Agric. Sci. Mansoura Univ., 34 (1): 679 - 701, 2009

Table (6): Effect of seed soaking of four chickpea cultivars in each of chemical inducers and neem oil on plant height and number of tillers/plant under naturally infection by S.sclerotiorum in field, at 120 days after planting in 2004/2005\& 2005/2006 seasons.

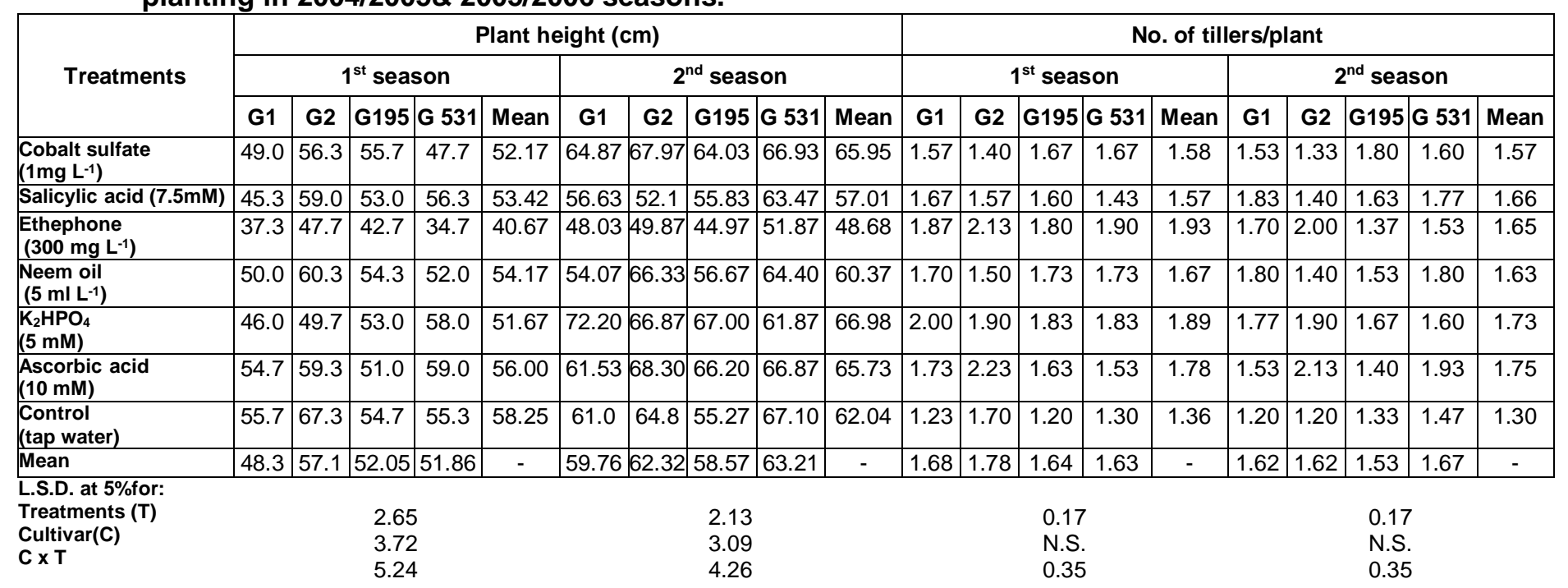


Rahmou, A. A. et al.

Table (7): Effect of seed soaking of four chickpea cultivars in each of chemical inducers and neem oil weight of 100 seeds $(\mathrm{g})$ and dry weight of plant $(\mathrm{g})$ under naturally infection by S.sclerotiorum in field, at harvest in $2004 / 2005 \& 2005 / 2006$ seasons.

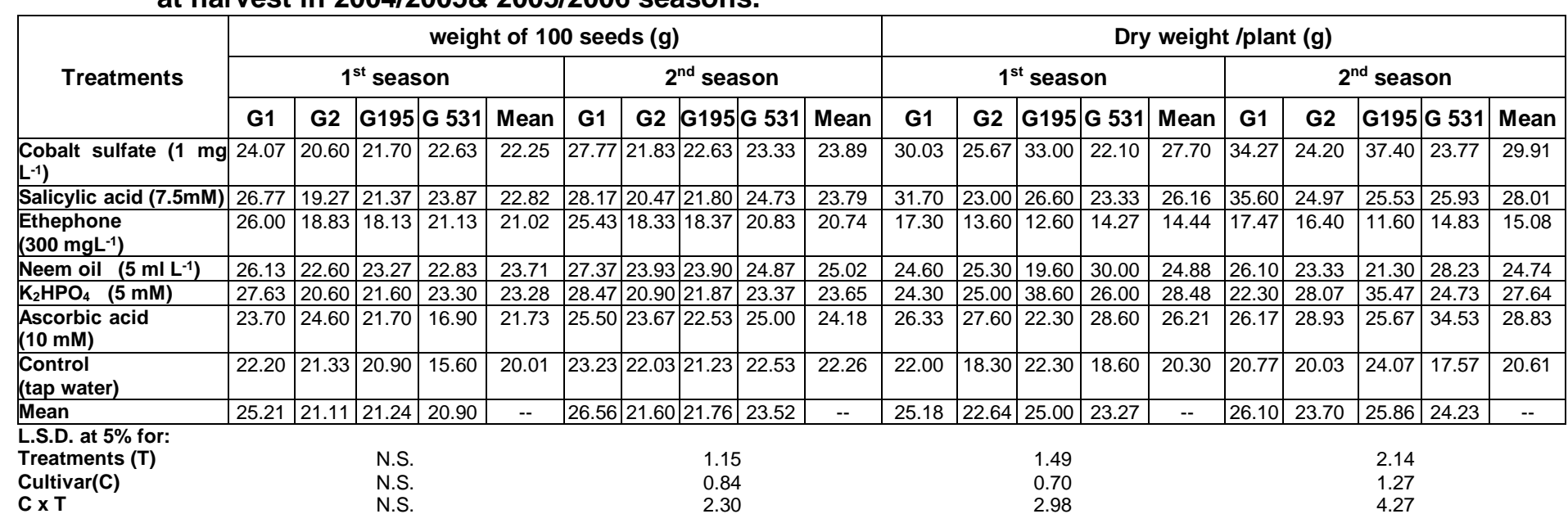




\section{J. Agric. Sci. Mansoura Univ., 34 (1), January, 2009}

Table (8): Effect of seed soaking of four chickpea cultivars in each of chemical inducers and neem oi on seeds weight/ plant (g) and number of capsules/plant under naturally infection by S.sclerotiorum in field, at harvest in 2004/2005\& 2005/2006 seasons.

\begin{tabular}{|c|c|c|c|c|c|c|c|c|c|c|c|c|c|c|c|c|c|c|c|c|}
\hline \multirow{3}{*}{ Treatments } & \multicolumn{10}{|c|}{ Seeds weight /plant (g) } & \multicolumn{10}{|c|}{ No. of capsules/plant } \\
\hline & \multicolumn{5}{|c|}{$1^{\text {st }}$ season } & \multicolumn{5}{|c|}{$2^{\text {nd }}$ season } & \multicolumn{5}{|c|}{$1^{\text {st }}$ season } & \multicolumn{5}{|c|}{$2^{\text {nd }}$ season } \\
\hline & G1 & G2 & G195 & G 531 & Mean & G1 & G2 & G195 & G 531 & Mean & G1 & G2 & G195 & G 531 & Mean & G1 & G2 & G195 & G 531 & Mean \\
\hline $\begin{array}{l}\text { Cobalt sulfate } \\
\left(1 \mathrm{mg} \mathrm{L}^{-1}\right)\end{array}$ & 22.30 & 21.67 & 26.93 & 24.93 & 23.96 & 23.90 & 23.50 & 26.90 & 26.80 & 25.28 & 93.67 & 104.67 & 128.00 & 122.67 & 112.25 & 91.67 & 103.0 & 120.3 & 114.67 & 107.41 \\
\hline $\begin{array}{l}\text { Salicylicacid } \\
\text { (7.5mM) }\end{array}$ & 23.80 & 24.90 & 27.47 & 22.47 & \begin{tabular}{|l|}
24.66 \\
\end{tabular} & 26.60 & 22.40 & \begin{tabular}{|l|}
25.47 \\
\end{tabular} & \begin{tabular}{|l|}
23.90 \\
\end{tabular} & \begin{tabular}{|l|}
24.59 \\
\end{tabular} & 98.00 & 108.33 & 133.00 & 128.00 & 116.83 & 94.67 & 108.67 & 130.0 & 127.0 & 115.09 \\
\hline $\begin{array}{l}\text { Ethephone } \\
\left(300 \mathrm{mg} \mathrm{L}^{-1}\right)\end{array}$ & 20.70 & 15.83 & 12.27 & 177.93 & 16.68 & 14.47 & 15.90 & \begin{tabular}{|l|}
11.70 \\
\end{tabular} & \begin{tabular}{|l|}
19.97 \\
\end{tabular} & \begin{tabular}{|l|}
15.51 \\
\end{tabular} & \begin{tabular}{|l|}
68.00 \\
\end{tabular} & \begin{tabular}{|l|}
80.00 \\
\end{tabular} & 61.33 & $\mid 101.00$ & \begin{tabular}{|l|}
77.58 \\
\end{tabular} & \begin{tabular}{|l|}
62.67 \\
\end{tabular} & 6.67 & 58.3 & 93.0 & 2.66 \\
\hline $\begin{array}{l}\text { Neem oil } \\
\left(5 \mathrm{ml} \mathrm{L}^{-1}\right)\end{array}$ & 28.83 & 23.10 & 28.20 & 22.43 & \begin{tabular}{|l|}
25.64 \\
\end{tabular} & 30.27 & 23.60 & 30.60 & \begin{tabular}{|l|}
27.80 \\
\end{tabular} & \begin{tabular}{|l|}
28.07 \\
\end{tabular} & 125.67 & 128.67 & 139.00 & 143.00 & 134.09 & 120.67 & \begin{tabular}{|l|}
124.0 \\
\end{tabular} & 132.0 & 137.7 & 128.59 \\
\hline $\begin{array}{l}\mathrm{K}_{2} \mathrm{HPO}_{4} \\
(5 \mathrm{mM})\end{array}$ & 33.30 & 28.20 & 31.57 & \begin{tabular}{|l|}
26.03 \\
\end{tabular} & \begin{tabular}{|l|}
29.78 \\
\end{tabular} & 30.87 & 24.07 & 33.20 & 30.60 & \begin{tabular}{|l|}
29.69 \\
\end{tabular} & 136.67 & 138.33 & 146.00 & \begin{tabular}{|l|}
147.00 \\
\end{tabular} & 142.00 & \begin{tabular}{|l|}
127.67 \\
\end{tabular} & \begin{tabular}{|l|}
134.3 \\
\end{tabular} & $\begin{array}{ll}141.3 \\
\end{array}$ & 144.3 & 136.89 \\
\hline $\begin{array}{l}\text { Ascorbic acid } \\
(10 \mathrm{mM})\end{array}$ & \begin{tabular}{|l|}
27.73 \\
\end{tabular} & 20.97 & 22.30 & \begin{tabular}{|l|}
23.27 \\
\end{tabular} & \begin{tabular}{|l|}
23.57 \\
\end{tabular} & 33.33 & 21.30 & \begin{tabular}{|l|}
24.13 \\
\end{tabular} & \begin{tabular}{|l|}
25.60 \\
\end{tabular} & 26.09 & 107.33 & 116.67 & 123.00 & 131.00 & 119.50 & 102.67 & 96.69 & 120.3 & 128.0 & 111.91 \\
\hline $\begin{array}{l}\text { Control } \\
\text { (tap water) }\end{array}$ & 21.53 & 19.50 & \begin{tabular}{|l|}
21.47 \\
\end{tabular} & 222.00 & 21.13 & 23.40 & 18.50 & 22.60 & \begin{tabular}{|l|}
22.80 \\
\end{tabular} & \begin{tabular}{|l|}
21.83 \\
\end{tabular} & \begin{tabular}{|l|}
90.33 \\
\end{tabular} & \begin{tabular}{|l|}
93.67 \\
\end{tabular} & 120.00 & \begin{tabular}{|l|}
118.00 \\
\end{tabular} & 105.50 & \begin{tabular}{|l|}
88.67 \\
\end{tabular} & 89.3 & 114.0 & 119.0 & 102.74 \\
\hline Mean & 25.46 & 22.02 & 24.32 & 22.72 & & 26.12 & 21.32 & 24.94 & 25.35 & - & 102.81 & $\mid 110.05$ & \begin{tabular}{|l}
121.48 \\
\end{tabular} & 127.24 & -- & 98.38 & 104.66 & 11116.62 & $\mid 123.38$ & - \\
\hline \multirow[t]{2}{*}{ L.S.D. at $5 \%$ for: } & & & 2.62 & & & & & & & & & & & & & & & 4. & & \\
\hline & & & $\begin{array}{l}1.79 \\
5.23\end{array}$ & & & & & $\begin{array}{l}1.47 \\
4.87\end{array}$ & & & & & $\begin{array}{l}3.88 \\
1019\end{array}$ & & & & & $\begin{array}{l}2.70 \\
8.26\end{array}$ & & \\
\hline
\end{tabular}


Rahmou, A. A. et al.

Table (9): Effect of seed soaking of four chickpea cultivars in each of chemical inducers and neem oil on seeds yield $(\mathrm{kg} / \mathrm{fed}$.) under naturally infection by S.sclerotiorum in field conditions at harvest in 2004/2005\& 2005/2006 seasons.

\begin{tabular}{|c|c|c|c|c|c|c|c|c|c|c|}
\hline \multirow{3}{*}{ Treatments } & \multicolumn{10}{|c|}{ Seeds yield (kg/feddan) } \\
\hline & \multicolumn{5}{|c|}{$1^{\text {st }}$ season } & \multicolumn{5}{|c|}{$2^{\text {nd }}$ season } \\
\hline & G1 & G2 & G195 & G 531 & Mean & G1 & G2 & G195 & G 531 & Mean \\
\hline $\begin{array}{l}\text { Cobalt sulfate } \\
\left(1 \mathrm{mg} \mathrm{L}^{-1}\right)\end{array}$ & 744.7 & 815.7 & 884.0 & 776.7 & 805.3 & 842.0 & 905.33 & 1045.33 & 890.67 & 920.83 \\
\hline $\begin{array}{l}\text { Salicylic acid } \\
\text { (7.5mM) }\end{array}$ & 872.3 & 689.3 & 758.0 & 691.3 & 752.7 & 989.33 & 759.67 & 855.33 & 803.00 & 851.83 \\
\hline $\begin{array}{l}\text { Ethephone } \\
\left(300 \mathrm{mgL}^{-1}\right)\end{array}$ & 373.7 & 376.3 & 364.0 & 466.0 & 395.0 & 330.33 & 368.00 & 315.37 & 507.00 & 380.17 \\
\hline $\begin{array}{l}\text { Neem oil } \\
\left(5 \mathrm{ml} \mathrm{L}^{-1}\right)\end{array}$ & 1104.7 & 839.3 & 996.7 & 925.0 & 996.4 & 1098.33 & 952.0 & 1229.67 & 1100.00 & 1095.00 \\
\hline $\begin{array}{l}\mathrm{K}_{2} \mathrm{HPO}_{4} \\
(5 \mathrm{mM})\end{array}$ & 1280.3 & 1012.3 & 1290.0 & 1163.3 & 1186.5 & 1502.67 & 1221.0 & 1439.67 & 1263.00 & 1356.58 \\
\hline $\begin{array}{l}\text { Ascorbic acid } \\
(10 \mathrm{mM})\end{array}$ & 828.7 & 725.0 & 750.0 & 703.3 & 751.8 & 841.67 & 810.33 & 837.67 & 820.66 & 827.58 \\
\hline $\begin{array}{l}\text { Control } \\
\text { (tap water) }\end{array}$ & 719.70 & 585.0 & 766.3 & 671.7 & 685.7 & 815.67 & 575.67 & 742.00 & 787.33 & 730.17 \\
\hline Mean & 846.3 & 720.4 & 829.66 & 771.0 & -- & 917.14 & 798.86 & 923.57 & 881.67 & -- \\
\hline \multicolumn{11}{|l|}{$\begin{array}{l}\text { L.S.D. at 5\%:for: } \\
\text { Treatments (T) } \\
\text { Cultivar(C) } \\
\text { C x T }\end{array}$} \\
\hline
\end{tabular}




\section{J. Agric. Sci. Mansoura Univ., 34 (1), January, 2009}

Table (10): Effect of seed soaking of four chickpea cultivars in each of chemical inducers and neem oil on removal $\mathrm{N}$ and protein content (kg/fed.) under naturally infection by S.sclerotiorum in field ,at harvest in 2004/2005 \& 2005/2006 seasons.

\begin{tabular}{|c|c|c|c|c|c|c|c|c|c|c|c|c|c|c|c|c|c|c|c|c|}
\hline \multirow{3}{*}{ Treatments } & \multicolumn{10}{|c|}{$N$ (kg/fed.) } & \multicolumn{10}{|c|}{ Protein (kg/fed.) } \\
\hline & \multicolumn{5}{|c|}{$1^{\text {st }}$ season } & \multicolumn{5}{|c|}{$2^{\text {nd }}$ season } & \multicolumn{5}{|c|}{$1^{\text {st }}$ season } & \multicolumn{5}{|c|}{$2^{\text {nd }}$ season } \\
\hline & G1 & G2 & G195 & G 531 & Mean & G1 & G2 & G195 & G 531 & Mean & G1 & G2 & G195 & G 531 & Mean & G1 & G2 & G195 & G 531 & Mean \\
\hline $\begin{array}{l}\text { Cobalt sulfate } \\
\left(1 \mathrm{mg} \mathrm{L}^{-1}\right)\end{array}$ & 31.28 & 39.15 & 38.90 & 34.95 & 36.1 & 35.26 & 43.46 & 46.00 & 40.08 & 41.20 & 195.85 & 244.70 & 243.98 & 216.69 & \begin{tabular}{|l|}
225.3 \\
\end{tabular} & 220.61 & 272.51 & 258.2 & 250.28 & 250.4 \\
\hline $\begin{array}{l}\text { Salicylic acid } \\
(7.5 \mathrm{mM})\end{array}$ & 40.13 & 31.71 & 36.38 & \begin{tabular}{|l|}
33.88 \\
\end{tabular} & \begin{tabular}{l|l}
35.5 \\
\end{tabular} & 46.18 & 34.95 & 41.06 & \begin{tabular}{|l|}
39.35 \\
\end{tabular} & \begin{tabular}{|l|}
40.38 \\
\end{tabular} & 251.23 & 199.22 & \begin{tabular}{|l|l|}
227.4 \\
\end{tabular} & 209.47 & \begin{tabular}{|l|}
221.8 \\
\end{tabular} & 282.95 & 220.30 & 255.8 & 244.92 & 250.98 \\
\hline $\begin{array}{l}\text { Ethephone } \\
\left(300 \mathrm{mgL}^{-1}\right)\end{array}$ & 15.32 & 12.80 & 16.02 & 19.57 & 15.9 & 14.54 & 12.52 & 13.88 & 21.29 & 15.55 & \begin{tabular}{|l|}
103.13 \\
\end{tabular} & 79.03 & 100.46 & 122.56 & \begin{tabular}{|l|}
101.3 \\
\end{tabular} & 90.18 & 78.02 & 86.72 & 133.34 & 97.06 \\
\hline $\begin{array}{l}\text { Neem } \\
\left(5 \mathrm{ml} \mathrm{L}^{-1}\right)\end{array}$ & 54.13 & 38.61 & 46.84 & \begin{tabular}{|l|}
45.33 \\
\end{tabular} & 46.2 & 53.82 & \begin{tabular}{|l|l|}
43.79 \\
\end{tabular} & 57.79 & 53.90 & \begin{tabular}{|l|}
52.33 \\
\end{tabular} & 338.03 & 242.57 & 293.02 & 283.05 & \begin{tabular}{|l|}
289.2 \\
\end{tabular} & 336.09 & 275.13 & 361.5 & 336.6 & 327.34 \\
\hline $\begin{array}{l}\mathrm{K}_{2} \mathrm{HPO}_{4} \\
(5 \mathrm{mM}) \\
\end{array}$ & 61.46 & 42.52 & 58.05 & \begin{tabular}{|l|}
54.68 \\
\end{tabular} & 54.2 & \begin{tabular}{|l|}
72.13 \\
\end{tabular} & \begin{tabular}{|l|}
51.28 \\
\end{tabular} & 64.79 & \begin{tabular}{|l|}
60.62 \\
\end{tabular} & \begin{tabular}{|l|}
62.20 \\
\end{tabular} & 384.10 & 266.24 & 362.49 & 342.02 & \begin{tabular}{|l|}
338.7 \\
\end{tabular} & 452.30 & 322.34 & \begin{tabular}{|l|l}
407.4 \\
\end{tabular} & 242.92 & 389.61 \\
\hline $\begin{array}{l}\text { Ascorbic acid } \\
(10 \mathrm{mM})\end{array}$ & 28.17 & 30.45 & 34.50 & 33.76 & 31.72 & 33.67 & 34.03 & 38.53 & 38.57 & 36.20 & 206.32 & 190.68 & 215.63 & 208.89 & \begin{tabular}{|l|}
318.0 \\
\end{tabular} & 211.26 & 213.93 & 242.09 & 242.92 & 227.55 \\
\hline $\begin{array}{l}\text { Control } \\
\text { (tap water) }\end{array}$ & 31.67 & 22.23 & 32.19 & 30.90 & 29.30 & \begin{tabular}{|l|}
35.89 \\
\end{tabular} & 22.00 & 31.16 & 37.01 & 31.52 & 198.63 & 138.06 & 201.55 & $\mid 194.11$ & \begin{tabular}{|l|}
183.1 \\
\end{tabular} & 223.49 & \begin{tabular}{|l|l|}
137.8 \\
\end{tabular} & 193.6 & 229.11 & 196.02 \\
\hline Mean & 37.45 & 31.07 & 37.55 & 37.15 & -- & \begin{tabular}{|l|l|}
41.64 \\
\end{tabular} & \begin{tabular}{|l|l|}
34.58 \\
\end{tabular} & 41.89 & 41.55 & -- & 239.61 & 194.36 & 234.93 & 225.26 & -- & 259.55 & 217.15 & 257.82 & 259.08 & -- \\
\hline \multirow{3}{*}{$\begin{array}{l}\text { L.S.D. at 5\%for: } \\
\text { Treatments (T) } \\
\text { Cultivar(C) } \\
\text { C x T }\end{array}$} & & & 2.14 & & & & & 3.34 & & & & & 14.00 & & & & & 20.83 & & \\
\hline & & & 1.91 & & & & & 3.34 & & & & & 14.32 & & & & & 20.56 & & \\
\hline & & & 4.28 & & & & & 6.68 & & & & & 28.65 & & & & & 41.65 & & \\
\hline
\end{tabular}


Rahmou, A. A. et al.

Table (11): Effect of seed soaking of four chickpea cultivars seeds in each of chemical inducers and neem oil on removal $P$ and $K$ (kg/fed.) under naturally infection by S.sclerotiorum in field , at harvest in 2004/2005\& 2005/2006 seasons

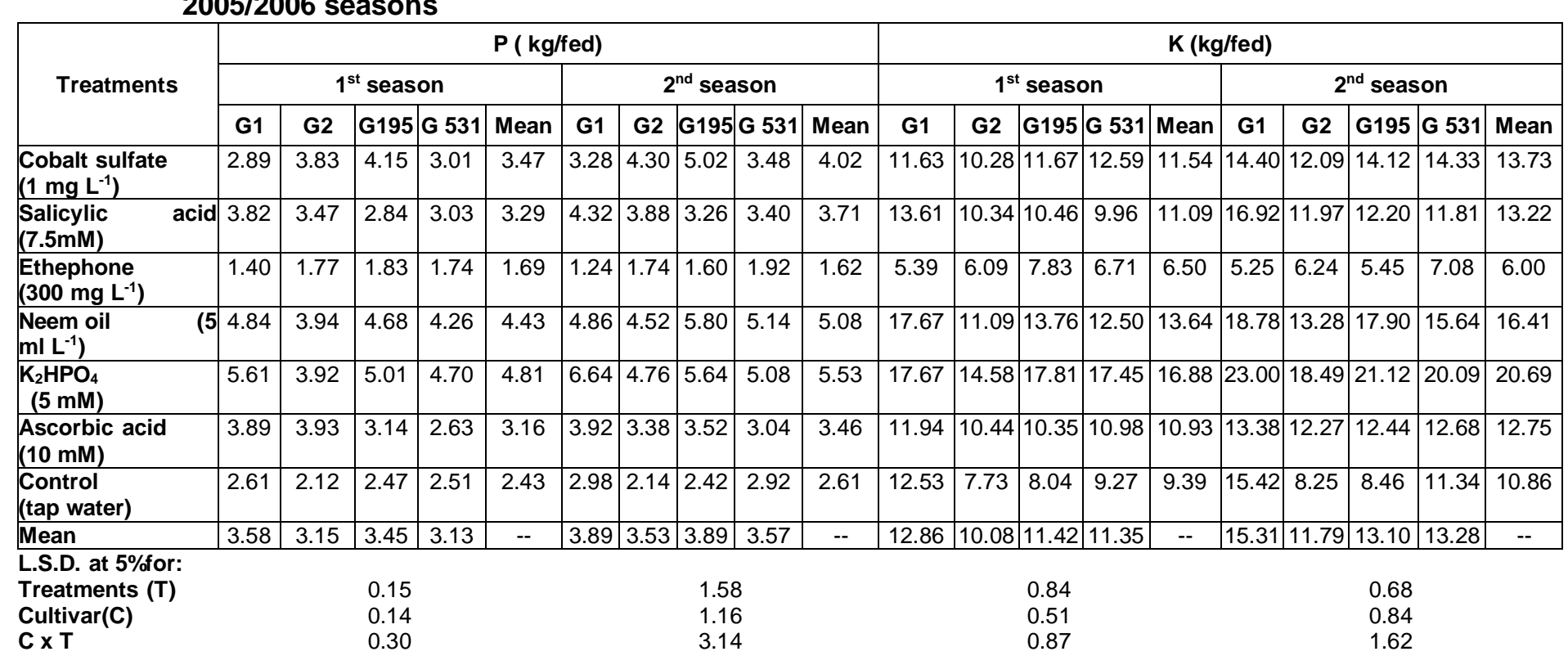


Table (5): Effect of seed soaking of four chickpea cultivars in each of chemical inducers and neem oil on white stem rot disease incidenc (\%) under naturally infection by S.sclerotiorum in field, at 90 and 120 days of planting in 2004/2005\& 2005/2006 seasons.

\begin{tabular}{|c|c|c|c|c|c|c|c|c|c|c|c|c|}
\hline \multirow{3}{*}{ Treatments } & \multicolumn{12}{|c|}{ Mean $\%$ of rot stem disease incidence( $1^{\text {st }}$ season $)$} \\
\hline & \multicolumn{3}{|c|}{ Giza 1} & \multicolumn{3}{|c|}{ Giza 2} & \multicolumn{3}{|c|}{ Giza 195} & \multicolumn{3}{|c|}{ Giza 531} \\
\hline & 90 days & 120 days & Mean & 90 days & 120 days & Mean & 90 days & 120 days & Mean & 90 days & 120 days & Mean \\
\hline Cobalt sulfate $\left(1 \mathrm{mg} \mathrm{L}^{-1}\right)$ & 6.2 & & 7.05 & $\begin{array}{ll}6.1 \\
7.3\end{array}$ & & 7.15 & 5.8 & 7.9 & 6.85 & 5.3 & 6.8 & $\begin{array}{l}6.05 \\
6.15 \\
\end{array}$ \\
\hline Salicylic acid $(7.5 \mathrm{mM})$ & $\begin{array}{ll}6.9 \\
8.5\end{array}$ & $\frac{7.9}{127}$ & 7.40 & 7.3 & 9.2 & 8.25 & $\frac{5.4}{81}$ & 7.6 & 6.50 & 5.4 & 6.9 & 6.15 \\
\hline Ethephone (300 $\left.\mathrm{mg} \mathrm{L}^{-1}\right)$ & 8.5 & & 10.60 & & & & & & 10.45 & 6.8 & 9.8 & 8.30 \\
\hline Neem oil $\left(5 \mathrm{ml} \mathrm{L}^{-1}\right)$ & 5.2 & 7.1 & 6.15 & 5.4 & 7.4 & 6.40 & 5.1 & 6.4 & 5.75 & 5.1 & 5.9 & 5.50 \\
\hline $\mathrm{K}_{2} \mathrm{HPO}_{4}(5 \mathrm{mM})$ & 3.9 & 6.7 & 5.30 & 4.8 & 6.8 & 5.80 & 3.8 & 6.3 & 5.05 & 3.5 & 4.7 & 4.10 \\
\hline Ascorbic acid(10 mM) & $\frac{.5}{7.5}$ & 8.12 & 7.85 & 7.0 & 9.4 & 8.00 & 4.0 & 7.5 & 6.12 & 5.0 & 7.8 & 6.40 \\
\hline Control & 9.1 & 13.9 & 11.50 & 9.5 & 15.7 & 12.60 & 8.8 & 12.9 & 10.85 & 7.6 & 9.7 & 8.65 \\
\hline Mean & 6.76 & 9.2 & & 7.03 & 10.03 & 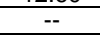 & 5.97 & 8.77 & 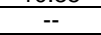 & 5.53 & 7.37 & \\
\hline $\begin{array}{l}\text { L.S.D. at 5\%for: } \\
\text { Treatments (T) } \\
\text { Period(P) } \\
\text { P x T }\end{array}$ & & $\begin{array}{l}1.48 \\
1.10 \\
2.10 \\
\end{array}$ & & & $\begin{array}{l}1.36 \\
1.48 \\
1.93 \\
\end{array}$ & & & $\begin{array}{l}1.34 \\
1.33 \\
\text { N.S. }\end{array}$ & & & $\begin{array}{l}0.96 \\
0.95 \\
\text { N.S. }\end{array}$ & \\
\hline \multirow{3}{*}{ Treatments } & \multicolumn{12}{|c|}{ Mean $\%$ of rot stem disease incidence $\left(2^{\text {nd }}\right.$ season $)$} \\
\hline & \multicolumn{3}{|c|}{ Giza 1} & \multicolumn{3}{|c|}{ Giza 2} & \multicolumn{3}{|c|}{ Giza 195} & \multicolumn{3}{|c|}{ Giza 531} \\
\hline & 90 days & 120 days & Mean & 90 days & 120 days & Mean & 90 days & 120 days & Mean & 90 days & 120 days & Mean \\
\hline Cobalt sulfate $\left(1 \mathrm{mg} \mathrm{L}^{-1}\right)$ & 5.9 & 7.5 & 6.70 & 6.2 & 9.2 & 7.70 & 5.3 & 7.5 & 6.40 & 5.0 & 5.8 & 5.40 \\
\hline Salicylic acid (7.5mM) & 6.5 & 9.1 & 7.80 & 7.2 & 10.7 & 8.95 & 6.1 & 8.9 & 7.50 & 5.8 & 6.3 & 6.05 \\
\hline Ethephone ( $\left.300 \mathrm{mgL}^{-1}\right)$ & 9.1 & 12.7 & 10.65 & 11.2 & 15.7 & 13.45 & 9.2 & 10.1 & 9.65 & 7.3 & 9.4 & 8.35 \\
\hline Neem oil $\left(5 \mathrm{ml} \mathrm{L}^{-1}\right)$ & 7.3 & 8.6 & 7.95 & 7.5 & 12.7 & 10.10 & 7.2 & 9.4 & 8.30 & 6.2 & 6.8 & 6.50 \\
\hline $\mathrm{K}_{2} \mathrm{HPO}_{4}(5 \mathrm{mM})$ & 6.3 & 8.7 & 7.50 & 7.7 & 11.2 & 9.45 & 6.5 & 8.1 & 7.30 & 5.3 & 5.8 & 5.55 \\
\hline Ascorbic acid (10 mM) & 8.2 & 10.6 & 9.40 & 9.9 & 14.1 & 12.00 & 7.2 & 8.8 & 8.00 & 6.9 & 7.3 & 7.10 \\
\hline Control & 10.9 & 15.7 & 13.30 & 12.1 & 17.3 & 14.70 & 9.8 & 12.4 & 11.10 & 8.4 & 10.6 & 9.50 \\
\hline & 7.74 & 10.41 & -- & 8.83 & 12.99 & $1 . .0$ & 7.33 & 9.31 & -- & 6.41 & 7.43 & -- \\
\hline $\begin{array}{l}\text { L.S.D. at } 5 \% \text { for: } \\
\text { Treatments (T) } \\
\text { Period (P) } \\
\text { P x T }\end{array}$ & \multicolumn{3}{|c|}{$\begin{array}{l}1.59 \\
1.26 \\
\text { N.S. }\end{array}$} & \multicolumn{3}{|c|}{$\begin{array}{l}1.63 \\
0.60 \\
\text { N.S. }\end{array}$} & \multicolumn{3}{|c|}{$\begin{array}{l}1.36 \\
1.42 \\
\text { N.S. }\end{array}$} & \multicolumn{3}{|c|}{$\begin{array}{l}0.78 \\
0.53 \\
\text { N.S. }\end{array}$} \\
\hline
\end{tabular}


Rahmou, A. A. et al.

Table (4): Effect of seed soaking of four chickpea cultivars in each of chemical inducers and neem oil on pre-emergence damping-off incidence and survival plants (\%) under artificially infection by S. sclerotiorum in greenhouse experiment.

\begin{tabular}{|c|c|c|c|c|c|c|c|c|c|c|c|c|c|}
\hline \multirow[b]{2}{*}{ Treatment } & \multirow[b]{2}{*}{ Concentration } & \multicolumn{3}{|c|}{ Giza 1} & \multicolumn{3}{|c|}{ Giza 2} & \multicolumn{3}{|c|}{ Giza 195} & \multicolumn{3}{|c|}{ Giza 531} \\
\hline & & $\begin{array}{c}\text { Pre- } \\
\%\end{array}$ & $\begin{array}{c}\text { Post - } \\
\%\end{array}$ & 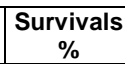 & $\begin{array}{c}\text { Pre- } \\
\%\end{array}$ & $\begin{array}{l}\text { Post- } \\
\%\end{array}$ & $\begin{array}{c}\text { Survivals } \\
\%\end{array}$ & $\begin{array}{c}\text { Pre- } \\
\%\end{array}$ & $\begin{array}{c}\text { Post- } \\
\%\end{array}$ & \begin{tabular}{|c} 
Survivals \\
$\%$
\end{tabular} & $\begin{array}{c}\text { Pre- } \\
\%\end{array}$ & $\begin{array}{c}\text { Post- } \\
\%\end{array}$ & $\begin{array}{c}\text { Survivals } \\
\%\end{array}$ \\
\hline Cobalt sulfate & $\begin{array}{l}0.5 \mathrm{mgL}^{-1} \\
1.0 \mathrm{mgL}^{-1} \\
2.0 \mathrm{mgL}^{-1}\end{array}$ & $\begin{array}{l}30 \\
20 \\
20\end{array}$ & $\begin{array}{l}15 \\
10 \\
20\end{array}$ & $\begin{array}{l}55 \\
70 \\
60\end{array}$ & $\begin{array}{l}40 \\
15 \\
25\end{array}$ & $\begin{array}{l}15 \\
15 \\
10\end{array}$ & $\begin{array}{l}45 \\
70 \\
65\end{array}$ & $\begin{array}{l}20 \\
10 \\
15\end{array}$ & $\begin{array}{l}15 \\
15 \\
20\end{array}$ & $\begin{array}{l}65 \\
75 \\
65\end{array}$ & $\begin{array}{l}20 \\
10 \\
20\end{array}$ & $\begin{array}{l}15 \\
10 \\
20\end{array}$ & $\begin{array}{l}65 \\
80 \\
60\end{array}$ \\
\hline Salicylic acid & $\begin{array}{l}2.5 \mathrm{mM} \\
5.0 \mathrm{mM} \\
7.5 \mathrm{mM}\end{array}$ & $\begin{array}{l}20 \\
30 \\
15 \\
15\end{array}$ & $\begin{array}{l}20 \\
20 \\
15\end{array}$ & $\begin{array}{l}50 \\
65 \\
70\end{array}$ & $\begin{array}{l}35 \\
25 \\
20\end{array}$ & $\begin{array}{l}10 \\
15 \\
10 \\
10\end{array}$ & $\begin{array}{l}50 \\
65 \\
70\end{array}$ & $\begin{array}{l}20 \\
15 \\
20\end{array}$ & $\begin{array}{l}20 \\
25 \\
20 \\
10\end{array}$ & $\begin{array}{l}05 \\
55 \\
65 \\
70\end{array}$ & $\begin{array}{l}20 \\
25 \\
15 \\
20\end{array}$ & $\begin{array}{l}20 \\
25 \\
20 \\
5\end{array}$ & $\begin{array}{l}50 \\
65 \\
75\end{array}$ \\
\hline Ethephone & $\begin{array}{l}100 \mathrm{mgL}^{-1} \\
200 \mathrm{mgL}^{-1} \\
300 \mathrm{mgL}^{-1}\end{array}$ & $\begin{array}{l}35 \\
35 \\
35\end{array}$ & $\begin{array}{l}25 \\
30 \\
25\end{array}$ & $\begin{array}{l}40 \\
35 \\
40\end{array}$ & $\begin{array}{l}40 \\
30 \\
40\end{array}$ & $\begin{array}{l}10 \\
25 \\
30 \\
15\end{array}$ & $\begin{array}{l}35 \\
40 \\
45\end{array}$ & $\begin{array}{l}20 \\
30 \\
35 \\
30\end{array}$ & $\begin{array}{l}20 \\
25 \\
25\end{array}$ & $\begin{array}{l}50 \\
40 \\
45\end{array}$ & $\begin{array}{l}20 \\
30 \\
30 \\
30\end{array}$ & $\begin{array}{l}30 \\
20 \\
20\end{array}$ & $\begin{array}{l}40 \\
50 \\
50\end{array}$ \\
\hline Neem oil & $\begin{array}{l}2.5 \mathrm{ml} \mathrm{L}^{-1} \\
5.0 \mathrm{ml} \mathrm{L}^{-1} \\
7.5 \mathrm{ml} \mathrm{L}^{-1}\end{array}$ & $\begin{array}{l}20 \\
15 \\
25\end{array}$ & $\begin{array}{l}15 \\
15 \\
15\end{array}$ & $\begin{array}{l}65 \\
70 \\
60\end{array}$ & $\begin{array}{l}25 \\
15 \\
25\end{array}$ & $\begin{array}{l}15 \\
15 \\
20\end{array}$ & $\begin{array}{l}60 \\
70 \\
55\end{array}$ & $\begin{array}{l}25 \\
10 \\
25\end{array}$ & $\begin{array}{l}20 \\
15 \\
20\end{array}$ & $\begin{array}{l}55 \\
75 \\
55\end{array}$ & $\begin{array}{l}15 \\
20 \\
20\end{array}$ & $\begin{array}{c}25 \\
5 \\
5 \\
25\end{array}$ & $\begin{array}{l}60 \\
75 \\
55\end{array}$ \\
\hline $\mathrm{K}_{2} \mathrm{HPO}_{4}$ & $\begin{array}{l}5.0 \mathrm{mM} \\
7.5 \mathrm{mM} \\
10.0 \mathrm{mM}\end{array}$ & $\begin{array}{l}30 \\
30 \\
25\end{array}$ & $\begin{array}{l}10 \\
20 \\
10\end{array}$ & $\begin{array}{l}70 \\
50 \\
65\end{array}$ & $\begin{array}{l}20 \\
35 \\
25\end{array}$ & $\begin{array}{l}10 \\
15 \\
25\end{array}$ & $\begin{array}{l}70 \\
50 \\
50\end{array}$ & $\begin{array}{l}15 \\
25 \\
30\end{array}$ & $\begin{array}{l}15 \\
25 \\
10\end{array}$ & $\begin{array}{l}70 \\
50 \\
60\end{array}$ & $\begin{array}{l}15 \\
25 \\
25\end{array}$ & $\begin{array}{l}10 \\
15 \\
25\end{array}$ & $\begin{array}{l}75 \\
60 \\
50\end{array}$ \\
\hline Ascorbic acid & $\begin{array}{l}5.0 \mathrm{mM} \\
7.5 \mathrm{mM} \\
10.0 \mathrm{mM}\end{array}$ & $\begin{array}{l}30 \\
30 \\
20 \\
\end{array}$ & $\begin{array}{c}15 \\
5 \\
10 \\
\end{array}$ & $\begin{array}{l}55 \\
65 \\
70 \\
\end{array}$ & $\begin{array}{l}40 \\
25 \\
20 \\
\end{array}$ & $\begin{array}{l}20 \\
20 \\
10 \\
\end{array}$ & $\begin{array}{l}40 \\
55 \\
70\end{array}$ & $\begin{array}{l}20 \\
20 \\
15\end{array}$ & $\begin{array}{l}25 \\
20 \\
15\end{array}$ & $\begin{array}{l}50 \\
55 \\
60 \\
70\end{array}$ & $\begin{array}{l}25 \\
25 \\
25 \\
15\end{array}$ & $\begin{array}{l}20 \\
20 \\
20 \\
15\end{array}$ & $\begin{array}{l}55 \\
55 \\
70\end{array}$ \\
\hline Control & & 30 & 25 & 45 & 40 & 30 & 30 & 25 & 25 & 50 & 20 & 10 & 70 \\
\hline $\begin{array}{l}\text { L.S.D. for: } \\
\text { Treatment (T) } \\
\text { Period (P) } \\
\text { T xP } \\
\text { Concentration } \\
\text { P x C } \\
\text { T x C } \\
\text { T x P x C } \\
\end{array}$ & (C) & & $\begin{array}{l}\text { N.S. } \\
1.53 \\
4.05 \\
\text { N.S. } \\
2.65 \\
\text { N.S. } \\
7.02\end{array}$ & & & $\begin{array}{l}\text { N.S. } \\
2.12 \\
5.61 \\
\text { N.S. } \\
3.67 \\
\text { N.S. } \\
9.71\end{array}$ & & & $\begin{array}{l}\text { N.S. } \\
1.82 \\
4.81 \\
\text { N.S. } \\
3.15 \\
\text { N.S. } \\
8.34\end{array}$ & & & $\begin{array}{l}\text { N.S. } \\
1.56 \\
4.12 \\
\text { N.S. } \\
2.69 \\
\text { N.S. } \\
7.13\end{array}$ & \\
\hline
\end{tabular}


J. Agric. Sci. Mansoura Univ., 34 (1), January, 2009 